\title{
Artemisinin-Daumone Hybrid Inhibits Cancer Cell-Mediated Osteolysis by Targeting Cancer Cells and Osteoclasts
}

\author{
Gwang Taek Ma ${ }^{a, b}$ Sun Kyoung Lee ${ }^{a}$ Kwang-Kyun Park ${ }^{a, b} \quad J u n h e e ~ P a r k a, c$ \\ Seung Hwa Son ${ }^{d}$ Mankil Junge Won-Yoon Chung ${ }^{a, b}$
}

aDepartment of Oral Biology, Oral Cancer Research Institute, BK21 PLUS Project, Yonsei University

College of Dentistry, Seoul, 'Department of Applied Life Science, The Graduate School, Yonsei

University, Seoul, 'Department of Dentistry, The Graduate School, Yonsei University, Seoul, dDepartment of Dental Hygiene, Gangdong College, Icheon, eDepartment of Chemistry, Yonsei University, Seoul, Korea

\section{Key Words}

Artemisinin $•$ Daumone $\cdot$ Hybrid molecules $•$ Bone metastasis $•$ Cancer-associated osteolysis

\begin{abstract}
Background/Aims: Bone metastasis of cancer cells decreases patient survival and quality of life. Hybridization via the covalent coupling of two bioactive natural products is a useful strategy for developing more potent anticancer agents by enhancing their bioavailability and avoiding drug resistance. Methods: The in vivo activities of artemisinin-daumone hybrid 15 (ARTD) were estimated in cancer cell-inoculated mice and ovariectomized mice. The viability, migration, and invasion of cancer cells were measured via MTT, wound-healing, and transwell invasion assays. ARTD-regulated transcription factors were detected with an $\mathrm{RT}^{2}$ profiler PCR array kit and Western blotting. Osteoclastogenesis and osteoclast activity were detected with tartrate-resistant acid phosphatase staining, a pit formation assay, gelatin zymography, and a cathepsin K ELISA assay. Results: ARTD blocked cancer-associated osteolysis more potently than artemisinin in mice with intratibially inoculated breast cancer or lung cancer cells. ARTD inhibited the viability, migration, and invasion of breast and lung cancer cells in the absence or presence of transforming growth factor- $\beta 1$. ARTD treatment induced the expression of tumor suppressive activating transcription factor 3 and inhibited oncogenic E2F transcription factor 1 expression at the mRNA and protein levels. ARTD inhibited receptor activator of nuclear factor kappa-B ligand-induced osteoclast formation and bone resorbing activity by reducing the secreted levels of matrix metalloproteinase- 9 and cathepsin K. Furthermore, ARTD prevented estrogen deficiency-induced bone loss in ovariectomized mice. Conclusion: ARTD may be a promising candidate for inhibiting cancer-induced bone destruction. The application of ARTD may be extended to patients with chemotherapy-induced ovarian failure or postmenopausal osteoporosis.
\end{abstract}

G. T. Ma and S. K. Lee contributed equally to this work. 


\section{Cellular Physiology Cell Physiol Biochem 2018;49:1460-1475 \begin{tabular}{l|l|l} 
DOI: 10.1159/000493449 & $\begin{array}{l}\text { O 2018 The Author(s). Published by S. Karger AG, Basel } \\
\text { www.karger.com/cpb }\end{array}$
\end{tabular} Ma et al.: Artemisinin-Daumone Hybrid Inhibits Cancer Cell-Mediated Osteolysis}

\section{Introduction}

Following the lungs and liver, bone is the third most common site of metastasis [1]. The majority of bony metastases are breast and prostate cancer, but lung cancer also frequently metastasizes to bone [2]. The incidence of bone metastasis in patients with an advanced stage of cancer is more than $75 \%$ for breast and prostate cancer and $26-50 \%$ for lung cancer. The median survival from the diagnosis of bone metastasis is 20 months for breast cancer, 12-53 months for prostate cancer, and 6 months for non-small-cell lung cancer (NSCLC) [3]. Bone metastases cannot be cured and cause complications, including moderate to severe hypercalcemia, pathologic fractures in the long bones and femur, nerve compression due to the epidural extension of tumors into the spine, and bone pain [4]. Currently, bisphosphonates (pyrophosphate analogs) and denosumab (a human monoclonal antibody against receptor activator of nuclear factor kappa-B ligand (RANKL)) are used clinically as the standard of care for cancer-induced bone destruction. However, long-term therapy with these bone-targeting agents causes side effects, including severe nephrotoxicity, osteonecrosis of the jaw, and atypical femoral fractures [5, 6]. Therefore, new and improved drugs and interventions with significant effects on skeletal metastases are required for promoting survival and quality of life in cancer patients.

Artemisinin (Fig. 1A) is an unusual sesquiterpene lactone with a 1,2,4-trioxane ring system that is found in the Chinese medicinal herb Artemisia annua, and artemisinin and its semisynthetic derivatives have been used in combination with other drugs to treat malaria caused by drug-resistant Plasmodium falciparum strains [7]. Furthermore, artemisinin and its derivatives have attracted attention as promising chemotherapeutic drug candidates because they have potent antineoplastic activity that acts through a variety of molecular mechanisms in both drug-sensitive and drug-resistant cancer cell lines [8-11]. This experimental evidence demonstrates the great potential of artemisinin compounds for use as a therapeutic alternative to treat highly aggressive cancers and for use as part of anticancer combination therapies without causing drug resistance or added side effects. However, the clinical application of artemisinins has been limited by its short half-life, poor bioavailability, and low solubility [9].

Hybrid molecules are combinations of two or more drugs that have different activities and mechanisms; these combinations improve the efficacy of the drugs by enhancing their bioavailability and transport across the membranes of cell organelles and by avoiding drug resistance $[12,13]$. Thus, hybridization via the covalent coupling of two biologically active natural products has been considered a useful strategy for developing more potent anticancer agents [14-16]. Recent studies have attempted to synthesize artemisinin hybrid molecules with diverse chemical structures [17-20]. Previously, we synthesized novel hybrid compounds using artemisinin and the glycolipid daumone, and found that many hybrids were more cytotoxic to human cancer cell lines than treatment with artemisinin or daumone alone [21]. Daumone (Fig. 1A), a pheromone isolated from Caenorhabditis elegans, is classified as a glycolipid [22]. Glycolipids act as natural biosurfactants with low or no toxicity; they are also biodegradable, have great stability under extreme conditions of $\mathrm{pH}$, salinity, and temperature, and enhance hydrocarbon solubility and mobility [23]. Therefore, glycolipids can be applied for use in cosmetic, food additive, and biomedical fields.

In the present study, to determine the therapeutic potential of artemisinin-daumone hybrid 15 (ARTD; Fig. 1A) against breast and lung cancer bone metastases, we investigated its inhibitory effects on cancer-induced osteolysis in a murine intratibial model, on the metastatic ability of MDA-MB-231 breast cancer and A549 lung cancer cells, on RANKLinduced osteoclastogenesis in osteoclast precursors, and on the bone resorptive activity of mature osteoclasts. We further identified ARTD-targeted transcription factors in both types of cancer cells. Finally, we investigated the effect of ARTD on estrogen deficiency-induced bone loss in ovariectomized mice. 


\section{Cellular Physiology Cell Physiol Biochem 2018;49:1460-1475

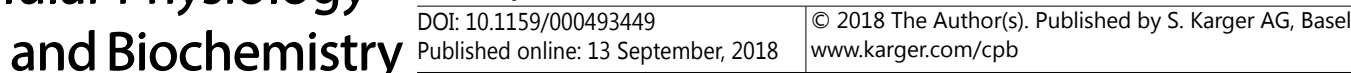 \\ Ma et al.: Artemisinin-Daumone Hybrid Inhibits Cancer Cell-Mediated Osteolysis}

\section{Materials and Methods}

\section{Reagents}

Artemisinin was purchased from LKT Laboratories (St. Paul, MN), and ARTD was provided by Professor Mankil Jung [21]. Minimum essential medium-alpha ( $\alpha$-MEM), RPMI 1640 medium, DMEM/nutrient mixture F-12 (DMEM/F-12) without phenol red, Dulbecco's PBS, HBSS, FBS, and antibiotic-antimycotic mixture were purchased from Gibco BRL (Grand Island, NY). TGF- $\beta 1$ was purchased from Peprotech (London, England). Histopaque-1083, 3-(4, 5-dimethylthiazol-2-yl)-2, 5-diphenyltetrazolium bromide (MTT), and 17 $\beta$-estradiol (E2) were purchased from Sigma-Aldrich (St. Louis, MO). Recombinant mouse soluble RANKL (sRANKL) and macrophage-colony-stimulating factor (M-CSF) were purchased from R \& D Systems (Minneapolis, MN). All reagents used in this study were of analytical grade.

\section{Animals}

Four-week-old male ICR and 5-week-old female BALB/c nude mice were obtained from NARA Biotech (Seoul, Korea). Eight-week-old female sham and ovariectomized (OVX) ICR mice were purchased from Central Lab Animal (Seoul, Korea). All animal studies were conducted in accordance with the experimental protocols approved by the Institutional Animal Care and Use Committee of Yonsei University College of Dentistry (IACUC approval nos. 2012-0324, 2015-0228, and 2015-0261). All methods were carried out in accordance with relevant guidelines and regulations.

\section{An intratibial model of cancer-induced bone destruction}

Five-week-old female BALB/c nude mice were anesthetized with a mixture of $30 \mathrm{mg} / \mathrm{kg}$ Zoletil (Virbac Laboratories, Carros, France) and $10 \mathrm{mg} / \mathrm{kg}$ Rompun (Byer Korea, Seoul, Korea). MDA-MB-231 or A549 cells ( $1 \times 10^{6}$ cells $/ 50 \mu \mathrm{L}$ HBSS $)$ were injected into the bone marrow of the right tibia of mice using a Hamilton syringe with a sterile 27 -gauge needle. Control mice received HBSS alone instead of cancer cells. The MDAMB-231 cell-injected mice ( $\mathrm{n}=8$ ) were administered vehicle (PBS containing 1\% DMSO and 1\% Tween-80), ARTD $(10$ or $20 \mathrm{mg} / \mathrm{kg})$, or artemisinin $(20 \mathrm{mg} / \mathrm{kg}$ ) by oral gavage 5 times per week and zoledronic acid $(0.1 \mathrm{mg} / \mathrm{kg})$ subcutaneously 3 times per week. The A549 cell-injected mice $(\mathrm{n}=5)$ were administered vehicle, ARTD (10 or $20 \mathrm{mg} / \mathrm{kg}$ ), or gefitinib $(10 \mathrm{mg} / \mathrm{kg}$ ) by oral gavage 5 times per week. After 6 weeks, microcomputed tomography $(\mu \mathrm{CT})$ analyses and histological examinations were performed as previously described, and bone metabolic markers in the sera were measured as previously described [24, 25]. Twodimensional (2D) and 3D images were generated using NRecon software (SkyScan, Aartselaar, Belgium). Bone morphometric parameters, including bone volume/tissue volume (BV/TV), trabecular thickness (Tb.Th), trabecular number (Tb.N), trabecular separation (Tb.Sp), and structure model index (SMI), were analyzed using CTAn software (Skyscan). Hematoxylin-eosin (H\&E) and tartrate-resistant acid phosphatase (TRAP) staining were also performed on the mouse hind limb sections. Tumor areas and osteoclast surface per bone surface (Oc.S/BS) values were measured with IMT i-Solution software (version 7.3, IMT i-Solution, $\mathrm{BC}$, Canada). Tumor areas were calculated as the percentage of the total tumor area per tissue area. Oc.S/ BS values were determined as the percentage of bone surface in contact with osteoclasts. Serum levels of calcium were determined using the QuantiChrome Calcium assay kit (BioAssay Systems, Hayward, CA), and those of TRAP $5 \mathrm{~b}$ and C-terminal cross-linking telopeptide of type I collagen (CTX) were measured by mouse TRAP assay kit (Immuno Diagnostic Systems, Boldon, UK) and RatLaps enzyme immunoassay kit (Immuno Diagnostic Systems), respectively.

\section{Cell lines and cell culture}

MDA-MB-231 human metastatic breast cancer and A549 human lung cancer cells (Korean cell line bank, Seoul, Korea) were grown in DMEM and RPMI 1640 medium, respectively, containing 10\% FBS and $1 \%$ antibiotic-antimycotic mixture at $37^{\circ} \mathrm{C}$ with $5 \% \mathrm{CO}_{2}$. Mouse bone marrow-derived macrophages (BMMs) were isolated from the tibiae of 4-week-old ICR male mice by histopaque density gradient centrifugation and cultured in $\alpha$-MEM containing $10 \%$ FBS, M-CSF (30 ng/mL), and $1 \%$ antibiotic-antimycotic mixture at $37^{\circ} \mathrm{C}$ with $5 \% \mathrm{CO}_{2}$.

\section{Cell viability assay}

MDA-MB-231 (5 × $10^{3}$ cells/well) or A549 ( $1 \times 10^{4}$ cells/well) cells were seeded in 96-well plates (SPL, Pocheon-Si, Korea) and treated with artemisinin or ARTD at the indicated concentrations in serum-free medium for $24 \mathrm{~h}, 48 \mathrm{~h}$, and $72 \mathrm{~h}$. BMMs (5 x $10^{4}$ cells/well) in 96-well plates were treated with artemisinin or ARTD at the indicated concentrations in the presence of M-CSF (30 ng/mL) for 5 days. Culture medium was replaced with fresh medium every second day. Cell viability was determined by an MTT assay. 


\section{Cellular Physiology Cell Physiol Biochem 2018;49:1460-1475 \begin{tabular}{ll|l} 
and Biochemistry Published online: 13 September, 2018 & $\begin{array}{l}\text { (c) } 2018 \text { The Author(s). Published by S. Karger AG, Basel } \\
\text { www.karger.com/cpb }\end{array}$ \\
\hline
\end{tabular}}

\section{Cell migration assay}

MDA-MB-231 ( 2 × $10^{5}$ cells/well) or A549 (5 x $10^{5}$ cells/well) cells were seeded in 6-well plates and incubated in DMEM and RPMI 1640 medium, respectively, with 10\% FBS. When the cells reached 95\% confluence, cell monolayers were scratched using the narrow end of a sterile micropipette tip. The detached cells were removed, and the wound area in each well was photographed immediately with a camera connected to a microscope. The cells were incubated in medium containing 1\% FBS (for MDA-MB-231 cells) or $2 \%$ FBS (for A549 cells), $1 \mu \mathrm{g} / \mathrm{mL}$ mitomycin C, and the indicated concentration of artemisinin or ARTD in the absence or presence of TGF- $\beta 1(10 \mathrm{ng} / \mathrm{mL})$. After $24 \mathrm{~h}$, each wound area was photographed. The width of the wound area was measured using Image J software, and the percentage of wound closure was derived by using the following formula as previously described: [1 - (final wound width/initial wound width)] $\mathrm{x}$ 100 [26].

\section{Cell invasion assay}

Cell invasion assays were conducted using Transwell chambers (Corning Costar, Cambridge, MA) as described previously [26]. The bottom of a polycarbonate filter insert was coated with gelatin $(1 \mathrm{mg} / \mathrm{ml})$, and the upper part was coated with Matrigel ( $1 \mathrm{mg} / \mathrm{mL}$; BD Biosciences, Palo Alto, CA). MDA-MB-231 (5 x $10^{4}$ cells $\left./ 100 \mu \mathrm{L}\right)$ or A549 $\left(1 \times 10^{5}\right.$ cells $\left./ 100 \mu \mathrm{L}\right)$ cells, the indicated concentrations of artemisinin or ARTD, and TGF- $\beta 1$ (10 ng/ml for MDA-MB-231 cells or $20 \mathrm{ng} / \mathrm{mL}$ for A549 cells) were added to the insert of each Matrigel-coated Transwell. The lower chamber contained $600 \mu \mathrm{L}$ of culture media with 1\% FBS (for MDAMB-231 cells) or 5\% FBS (for A549 cells) as the chemoattractant. The Transwell chambers were incubated for $24 \mathrm{~h}$ (for MDA-MB-231 cells) or $48 \mathrm{~h}$ (for A549 cells) at $37^{\circ} \mathrm{C}$. The cells were then fixed with $70 \%$ methanol, and the membranes were stained with hematoxylin. Noninvaded cells on the upper surface of the insert were scraped with cotton swabs, and the cells that invaded into the gelatin membrane on the bottom surface were mounted on slides. The stained cells were counted using a Zeiss Axio Imager microscope (Carl Zeiss, Gottingen, Germany).

\section{PCR array of human transcription factors}

Total RNA was isolated from MDA-MB-231 or A549 cells treated with ARTD (5 $\mu \mathrm{M})$ using the RNeasy mini kit (Qiagen, Valencia, CA). RNA ( $2 \mu \mathrm{g}$ ) was then converted to cDNA using the RT ${ }^{2}$ first strand kit (Sabioscience, Frederick, MD). The cDNA was mixed with RT ${ }^{2}$ SYBR Green ROX qPCR Master Mix (Sabioscience), and this mixture was aliquoted into the wells of a RT ${ }^{2}$ profiler PCR array plate (PAHS-075ZA, Human Transcription Factor, Sabioscience). Quantitative real-time PCR and data analyses were conducted as previously described [24]. The mRNA expression of each gene was normalized to the expression of the following housekeeping genes: GAPDH, beta 2-microglobulin, hypoxanthine phosphoribosyl-transferase 1, ribosomal protein L13a, and beta-actin. Changes in the gene expression levels in MDA-MB-231 or A549 cells treated with ARTD are expressed as a fold-change using the comparative $\Delta \mathrm{Ct}$ method.

\section{Analysis of cancer microarray data using the Oncomine public database}

The Oncomine database (http://www.oncomine.org) was used to analyze the gene expression levels of the transcription factors activating transcription factor 3 (ATF3), E2F transcription factor 1 (E2F1), and hepatocyte nuclear factor 4 alpha (HNF $4 \alpha$ ) in breast and lung cancer tissues compared those in normal tissues. Oncomine processes and normalizes each dataset used for these analyses independently.

\section{Western blot analysis}

MDA-MB-231 and A549 cells ( 1 × $10^{6}$ cells/60 mm dish) were treated with artemisinin or ARTD at the indicated concentrations for $24 \mathrm{~h}$. Cell lysates were prepared using RIPA buffer (Thermo Scientific, Rockford, IL) containing a protease inhibitor cocktail (Roche Diagnostics, Penzberg, Germany). Lysates were centrifuged at 22, $000 \mathrm{x} \mathrm{g}$ for $15 \mathrm{~min}$ at $4^{\circ} \mathrm{C}$. The protein levels in the supernatants were measured using bicinchoninic acid assay reagents (Thermo Scientific). Proteins (30 $\mu$ g) were separated on a $10 \%$ sodium dodecyl sulfate-polyacrylamide gel and electrotransferred onto a polyvinylidene difluoride membrane (Millipore, Danvers, MA). The membrane was blocked with 5\% skim milk in Tris-buffered saline $(150 \mathrm{mM}$ $\mathrm{NaCl}, 10 \mathrm{mM}$ Tris, $\mathrm{pH}$ 8.0) with $0.1 \%$ (w/v) Tween 20 and then incubated with primary antibodies against ATF3 (cat\# sc-188), E2F1 (cat\# sc-251), HNF4 $\alpha$ (cat\# sc-374229), or GAPDH (cat\# sc-32233) (Santa Cruz Biotechnology, Santa Cruz, CA), followed by incubation with horseradish peroxide-conjugated secondary antibodies for $1 \mathrm{~h}$. The targeted proteins were visualized with Amersham ECL Western Blotting Detection Reagents (GE Healthcare, Buckinghamshire, UK) and quantitatively measured with an image densitometer (ImageMaster VDS CI, Amersham Biosciences Europe, IT). 


\section{Cellular Physiology Cell Physiol Biochem 2018:49:1460-1475

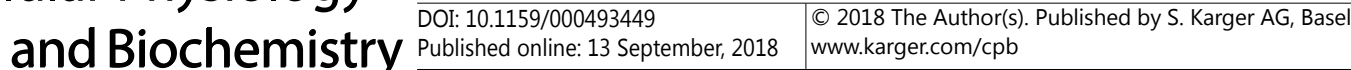

Osteoclast formation assay

BMMs were seeded at a density of $5 \times 10^{4}$ cells/well in 96-well plates with $\alpha$-MEM containing $10 \%$ FBS and treated with artemisinin or ARTD at the indicated concentrations in the presence of M-CSF $(30 \mathrm{ng} / \mathrm{mL})$ and sRANKL (100 ng/mL) for 5 days. Culture medium was replaced with fresh medium every second day. The cells were fixed with $3.7 \%$ formaldehyde for $1 \mathrm{~min}$ and stained using the Acid Phosphatase Leukocyte Kit (Sigma-Aldrich). The number of osteoclasts was determined by counting the multinucleated ( $\geq 3$ nuclei) TRAP-positive cells using a light microscope (original magnification, $\mathrm{x} 40$ ).

\section{Pit formation assay}

BMMs were seeded at a density of $5 \times 10^{4}$ cells/well in Osteo Assay Stripwell Plates (Corning Costar, Cambridge, MA) and cultured in $\alpha$-MEM containing 10\% FBS in the presence of M-CSF (30 ng/mL) and sRANKL $(100 \mathrm{ng} / \mathrm{mL})$ for 5 days. BMMs were then treated with artemisinin or ARTD at the indicated concentrations in the presence of M-CSF $(30 \mathrm{ng} / \mathrm{mL})$ and sRANKL $(100 \mathrm{ng} / \mathrm{mL})$ for an additional 8 days. The medium was replaced every second day and collected for gelatin zymography and a cathepsin K assay. The BMMs on the plate were lysed with a 5\% sodium hypochlorite solution. Images of resorbed pits were obtained using a light microscope (original magnification, x100).

\section{Gelatin zymography and cathepsin Kassay}

The protein concentration of the collected medium was determined using the Pierce BCA Protein Assay Kit (Thermo Scientific). The proteins (30 $\mu \mathrm{g}$ ) were separated on an $8 \%$ sodium dodecyl sulfatepolyacrylamide gel containing $0.2 \%(\mathrm{w} / \mathrm{v})$ gelatin. After electrophoresis, the gel was washed twice with $2.5 \%$ Triton $\mathrm{X}-100$ for $1 \mathrm{~h}$ at room temperature and incubated in buffer containing $50 \mathrm{mM}$ Tris- $\mathrm{HCl}(\mathrm{pH}$ 7.4), $0.02 \% \mathrm{NaN}_{3}, 10 \mathrm{mM} \mathrm{CaCl}_{2}$, and $150 \mathrm{mM} \mathrm{NaCl}$ for $24 \mathrm{~h}$ at $37^{\circ} \mathrm{C}$. The gel was stained with a solution of $0.1 \%$ Coomassie brilliant blue R-250 (Fluka Chemie, AG, NeuUlm, Switzerland). Clear zones against the blue background indicate the gelatinolytic activity of MMPs. Cathepsin K levels in the culture media were determined using a SensiZyme cathepsin Kactivity assay kit (Sigma-Aldrich) according to the manufacturer's instructions [26].

\section{Animal model of ovariectomy-induced bone loss}

Eight-week-old female OVX mice were divided into 4 groups of 10 mice and administered vehicle, ARTD ( 1 or $5 \mathrm{mg} / \mathrm{kg}$ ), or E2 $(0.1 \mathrm{mg} / \mathrm{kg})$ by oral gavage 5 times per week for 12 weeks. Sham-operated mice received the vehicle alone. $\mu \mathrm{CT}$ analyses, histological examinations, and detection of bone metabolic markers in sera were performed as described in the section An intratibial model of cancer-induced bone destruction. Serum levels of alkaline phosphatase (ALP) were determined using the QuantiChrome ALP Assay Kit (BioAssay Systems, Hayward, CA), and those of osteocalcin were measured using the Osteocalcin Enzyme Immunoassay Kit (Biomedical Technologies, Stoughton, MA). TNF- $\alpha$ and IL-1 $\beta$ levels were quantified using their respective commercially available ELISA kits (R\&D Systems).

\section{Statistical analysis}

The data are expressed as the mean \pm SEM of three independent experiments. Statistical analyses were performed using one-way analysis of variance (ANOVA) and Tukey's test to determine differences between two groups. The results with $P<0.05$ were considered statistically significant. Statistical analysis was performed using SPSS software ver. 20.0 (SPSS, Chicago, IL).

\section{Results}

The inhibitory effects of ARTD on cancer cell-induced bone destruction in mice

The in vivo inhibitory effects of ARTD on cancer cell-mediated osteolysis were first examined in mice intratibially injected with breast cancer or lung cancer cells, which are most often responsible for metastatic bone diseases. The oral administration of ARTD for 6 weeks dose-dependently blocked the induction of severe osteolytic lesions in the tibiae of MDA-MB-231 cell-injected mice, as shown by X-ray and 3D images derived from $\mu \mathrm{CT}$ analyses (Fig. 1B). In particular, ARTD treatment at $20 \mathrm{mg} / \mathrm{kg}$ restored the decreased BV/ TV, Tb.Th, and Tb.N values and blunted the increased Tb.Sp and SMI values to those of the controls in vehicle-treated mice (Fig. 1C). H\&E and TRAP staining indicated that ARTD treatment inhibited the growth of MDA-MB-231 breast cancer cells in the bone marrow of mouse tibiae (Fig. 1D and E) and the formation of TRAP-positive osteoclasts on the bone surfaces close to the tumor masses (Fig. 1D and F). The serum levels of calcium, TRAP5b, 


\section{Cellular Physiology Cell Physiol Biochem 2018;49:1460-1475

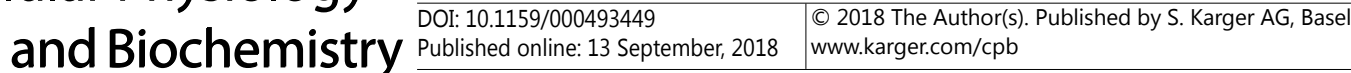 \\ Ma et al.: Artemisinin-Daumone Hybrid Inhibits Cancer Cell-Mediated Osteolysis}

and CTX that were elevated after MDA-MB-231 cell inoculation were also inhibited by ARTD treatment (Fig. 1G). ARTD treatment at $20 \mathrm{mg} / \mathrm{kg}$ inhibited tumor growth and the generation of osteolytic lesions more potently than treatment with artemisinin at the same dose, but orally administered ARTD at $20 \mathrm{mg} / \mathrm{kg}$ was not more potent than subcutaneously injected zoledronic acid at $0.1 \mathrm{mg} / \mathrm{kg}$. ARTD and artemisinin at the administered doses did not affect the serum levels of alanine aminotransferase (ALT) or aspartate aminotransferase (AST), which are indicators of hepatotoxicity, or serum blood urea nitrogen (BUN) or creatinine levels, which are indicators of nephrotoxicity (Fig. S1A - For all supplemental material see www.karger.com/ 10.1159/000493449/).

In mice inoculated with A549 NSCLC cells, oral administration of ARTD also decreased the production of osteolytic lesions in a dose-dependent manner, as shown by X-ray and 3D images (Fig. 2A), bone morphometric parameter analyses (Fig. 2B), H\&E and TRAP staining (Fig. 2C), tumor area in the bone marrow (Fig. 2D), osteoclast formation at the tumor-bone interface (Fig. 2E), and serum levels of bone metabolic markers (Fig. 2F). ARTD at $20 \mathrm{mg} /$ $\mathrm{kg}$ was as effective as gefitinib at $10 \mathrm{mg} / \mathrm{kg}$. Tissue damage in the liver and kidneys was not observed in A549 cell-inoculated mice orally administered ARTD (Fig. S1B).

The inhibitory effects of ARTD on the metastatic ability of breast and lung cancer cells

We investigated whether ARTD treatment could significantly inhibit the viability, migration, and invasion of cancer cells. ARTD at lower concentrations dose- and timedependently reduced the viability of MDA-MB-231 breast cancer (Fig. 3A) and A549 NSCLC cells (Fig. 3B), whereas artemisinin treatment at up to $80 \mu \mathrm{M}$ did not show marked cytotoxic activity. Treatment with ARTD and artemisinin at noncytotoxic concentrations for $24 \mathrm{~h}$ inhibited the migration of MDA-MB-231 (Fig. 3C) and A549 cells (Fig. 3D) in the absence or presence of TGF- $\beta$. Treatment with $20 \mu \mathrm{M}$ artemisinin and $2.5 \mu \mathrm{M}$ ARTD inhibited the migration of MDA-MB-231 cells by $11 \%$ and 19\%, respectively, and that of A549 cells by $17 \%$ and $38 \%$, respectively. Treatment with $20 \mu \mathrm{M}$ artemisinin and $2.5 \mu \mathrm{M}$ ARTD inhibited the migration of TGF- $\beta$-stimulated MDA-MB-231 cells by $25 \%$ and $30 \%$, respectively, and that of TGF- $\beta$-stimulated A549 cells by $19 \%$ and $40 \%$, respectively. In addition, treatment with ARTD and artemisinin at noncytotoxic concentrations for $24 \mathrm{~h}$ potently inhibited the invasion of MDA-MB-231 (Fig. 3E) and A549 cells (Fig. 3F) in the absence or presence of TGF- $\beta$. In MDA-MB-231 cells, $20 \mu \mathrm{M}$ artemisinin and $2.5 \mu \mathrm{M}$ ARTD inhibited cell invasion by $36 \%$ and $53 \%$, respectively, and TGF- $\beta$-induced invasion by $43 \%$ and $63 \%$, respectively. In A549 cells, $20 \mu \mathrm{M}$ artemisinin and $2.5 \mu \mathrm{M}$ ARTD inhibited cell invasion by $76 \%$ and $85 \%$ and TGF- $\beta$-induced invasion by $30 \%$ and $70 \%$, respectively.

Transcription factors targeted by ARTD in MDA-MB-231 and A549 cells and the correlation between their gene expression levels and breast or lung cancer

To identify target molecules closely related to the antimetastatic effects of ARTD, we used PCR arrays to examine the altered expression of human transcription factors in MDAMB-231 and A549 cells exposed to ARTD. ARTD treatment resulted in the upregulation of ATF3 mRNA and the downregulation of E2F1 and HNF4A mRNA in both MDA-MB-231 (Fig. 4A and Table S1) and A549 cells (Fig. 4A and Table S2). mRNA levels of CCAAT/enhancer binding protein gamma (CEBPG) and early growth response 1 (EGR1) were also upregulated, but the increase was not significant. The clinical importance of these transcription factors was analyzed by using microarray data from patients with breast and lung cancer from the Oncomine database. ATF3 expression levels were significantly downregulated and E2F1 gene expression levels were upregulated in the tissues of breast and lung cancer patients compared with those in noncancer tissues. Significantly upregulated HNF4 $\alpha$ gene expression was observed in lung cancer tissues (Fig. 4B). According to the Western blot analyses, artemisinin and ARTD treatment induced ATF3 protein expression and decreased E2F1 protein expression in MDA-MB-231 and A549 cells. HNF4 $\alpha$ expression levels were inhibited by ARTD treatment in MDA-MB-231 and A549 cells, but artemisinin treatment at higher concentrations inhibited the expression levels of these proteins in A549 cells (Fig. 4C). 


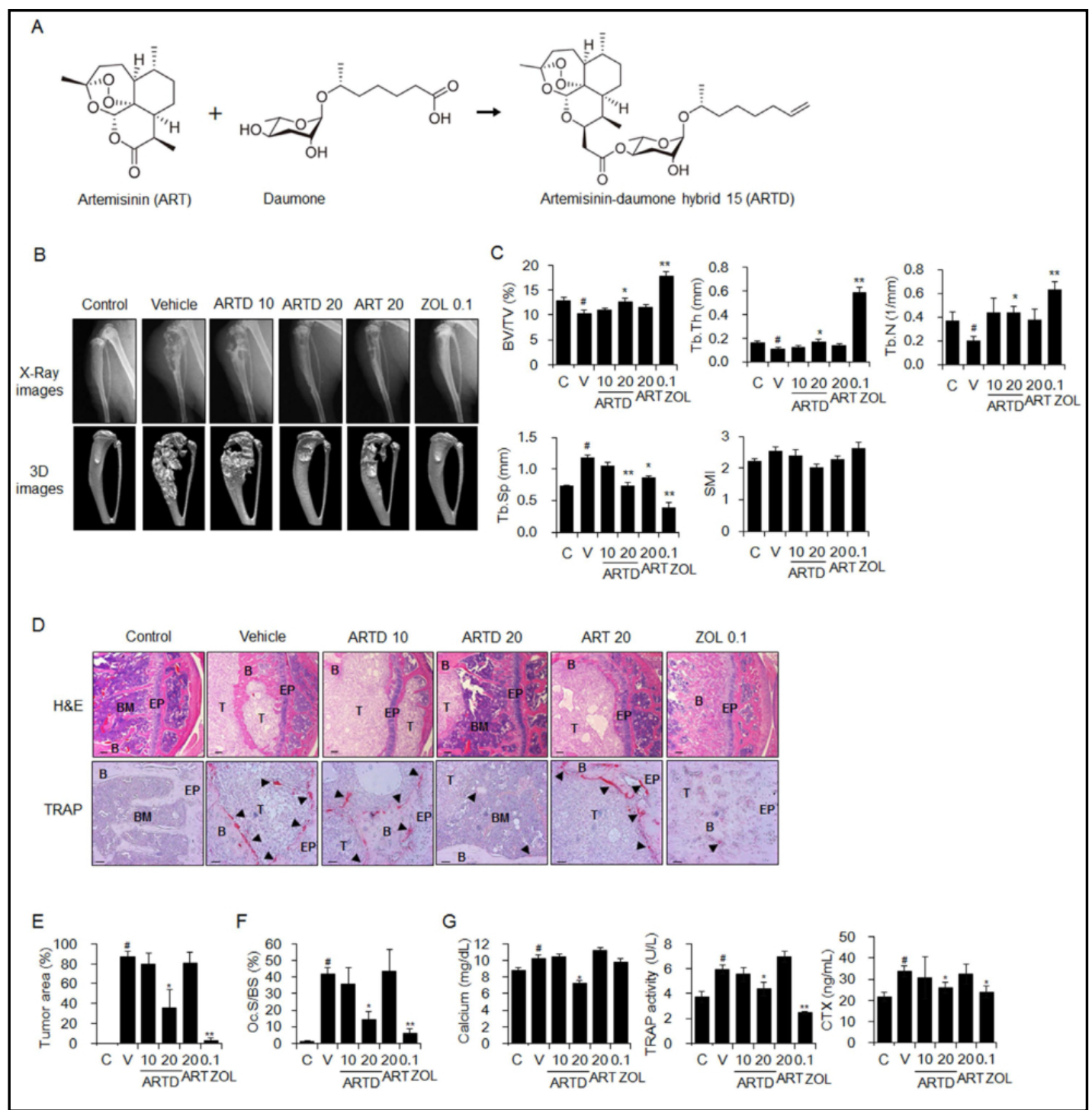

Fig. 1. The inhibitory effects of ARTD on breast cancer cell-induced osteolysis in mice. MDA-MB-231 cells were injected into the bone marrow of right tibiae in mice. Control mice received HBSS only. The mice injected with MDA-MB-231 cells $(\mathrm{n}=8)$ were administered vehicle (PBS containing 1\% DMSO and 1\% Tween-80), ARTD (10 and $20 \mathrm{mg} / \mathrm{kg}$ ), or artemisinin (ART, $20 \mathrm{mg} / \mathrm{kg}$ ) by oral gavage 5 times per week and zoledronic acid (ZOL, $0.1 \mathrm{mg} / \mathrm{kg}$ ) subcutaneously 3 times per week for 6 weeks. (A) Chemical structures of artemisinin, daumone, and ARTD. (B) Radiographic and 3D images of mouse tibiae derived from $\mu$ CT scans. (C) Bone morphometric parameters of tibiae derived from $\mu \mathrm{CT}$ analysis. (D) H\&E and TRAP staining of tibial tissues. Arrowheads: TRAP-positive osteoclasts; T: tumor; B: bone; BM: bone marrow; EP: epiphyseal plate. Scale bar: $0.246 \mathrm{~mm}$ for H\&E staining and $10 \mu \mathrm{m}$ for TRAP staining. (E) Tumor areas and (F) osteoclast surface per bone surface (Oc.S/BS) values for stained tibia sections. (G) Serum levels of bone resorption markers, calcium, TRAP5b, and CTX. Data are expressed as the mean \pm SEM. ${ }^{*} \mathrm{P}<0.05$ versus control (C) mice, ${ }^{*} \mathrm{P}<0.05 ; * \mathrm{P}<0.01$ versus vehicle-treated $(\mathrm{V})$ mice.

\section{The inhibitory effects of ARTD on the formation and activity of osteoclasts}

We determined the concentrations of artemisinin and ARTD that were noncytotoxic to BMMs by investigating the viability of BMMs treated with artemisinin and ARTD in the presence of M-CSF for 5 days. Artemisinin did not reduce the viability of BMMs at up to $80 \mu \mathrm{M}$. ARTD inhibited cell viability by $73 \%$ at $1 \mu \mathrm{M}$ but did not affect cell viability at less than $0.5 \mu \mathrm{M}$ (Fig. S2). When BMMs were treated with artemisinin and ARTD at 


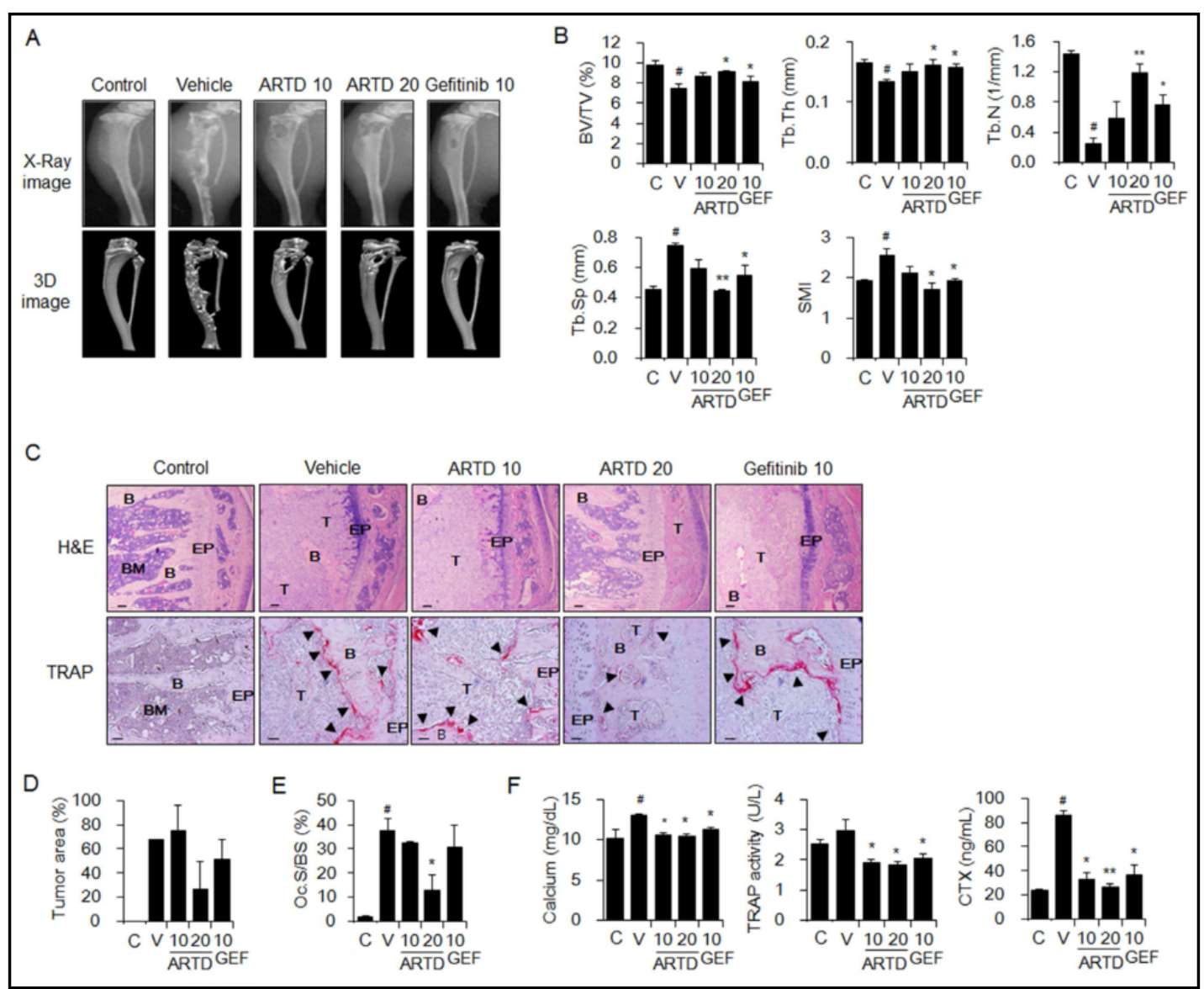

Fig. 2. The inhibitory effects of ARTD on NSCLC-induced osteolysis in mice. A549 cells were injected into the bone marrow of the right tibiae in mice. Control mice received HBSS only. The mice injected with A549 cells $(n=5)$ were administered vehicle (PBS containing 1\% DMSO and 1\% Tween-80), ARTD (10 or 20 mg/ $\mathrm{kg}$ ), or gefitinib (GEF, $10 \mathrm{mg} / \mathrm{kg}$ ) by oral gavage 5 times per week for 6 weeks. (A) Radiographic and 3D images derived from $\mu \mathrm{CT}$ scans. (B) Bone morphometric parameters of tibiae derived from $\mu \mathrm{CT}$ analysis. (C) H\&E and TRAP staining of tibia tissues. Arrowheads: TRAP-positive osteoclasts; T: tumor; B: bone; BM: bone marrow; EP: epiphyseal plate. Scale bar: $0.246 \mathrm{~mm}$ for H\&E staining and $10 \mu \mathrm{m}$ for TRAP staining. (D) Tumor areas and (E) osteoclast surface per bone surface (Oc.S/BS) values for stained tibia sections. (F) Serum levels of bone resorption markers. Data are expressed as the mean $\pm \mathrm{SEM}$. ${ }^{\sharp} \mathrm{P}<0.05$ versus control (C) mice, ${ }^{*} \mathrm{P}<0.05 ;{ }^{* *} \mathrm{P}<0.01$ versus vehicle-treated $(\mathrm{V})$ mice.

noncytotoxic concentrations in the presence of M-CSF and RANKL for 5 days, RANKLinduced osteoclastogenesis was blocked in a dose-dependent manner. Treatment with $5 \mu \mathrm{M}$ artemisinin and $0.3 \mu \mathrm{M}$ ARTD inhibited osteoclast formation by more than $90 \%$ (Fig. 5A). When BMMs were treated with artemisinin and ARTD after the differentiation of osteoclast precursors to mature osteoclasts, ARTD prevented the formation of resorptive pits on calcium phosphate-coated plates (Fig. 5B). After RANKL treatment, pro- and active-MMP-9 levels (Fig. 5C) and cathepsin K activity (Fig. 5D) were increased in the culture medium of differentiated osteoclasts, but the enhanced activities of these proteases were considerably inhibited by ARTD treatment. However, artemisinin at higher concentrations than ARTD did not reduce osteoclast-mediated pit formation or protease activity.

The inhibitory effect of ARTD on estrogen deficiency-induced bone loss

We further assessed the inhibitory effects of ARTD on bone loss in OVX mice, an animal model of estrogen deficiency-induced osteoporosis. In 3D images of femora trabecular bones that were reconstructed using $\mu \mathrm{CT}$ data, OVX-induced trabecular bone loss was inhibited by ARTD treatment in a dose-dependent manner (Fig. 6A). Weight gain in OVX mice was

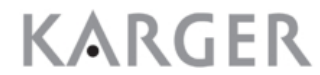




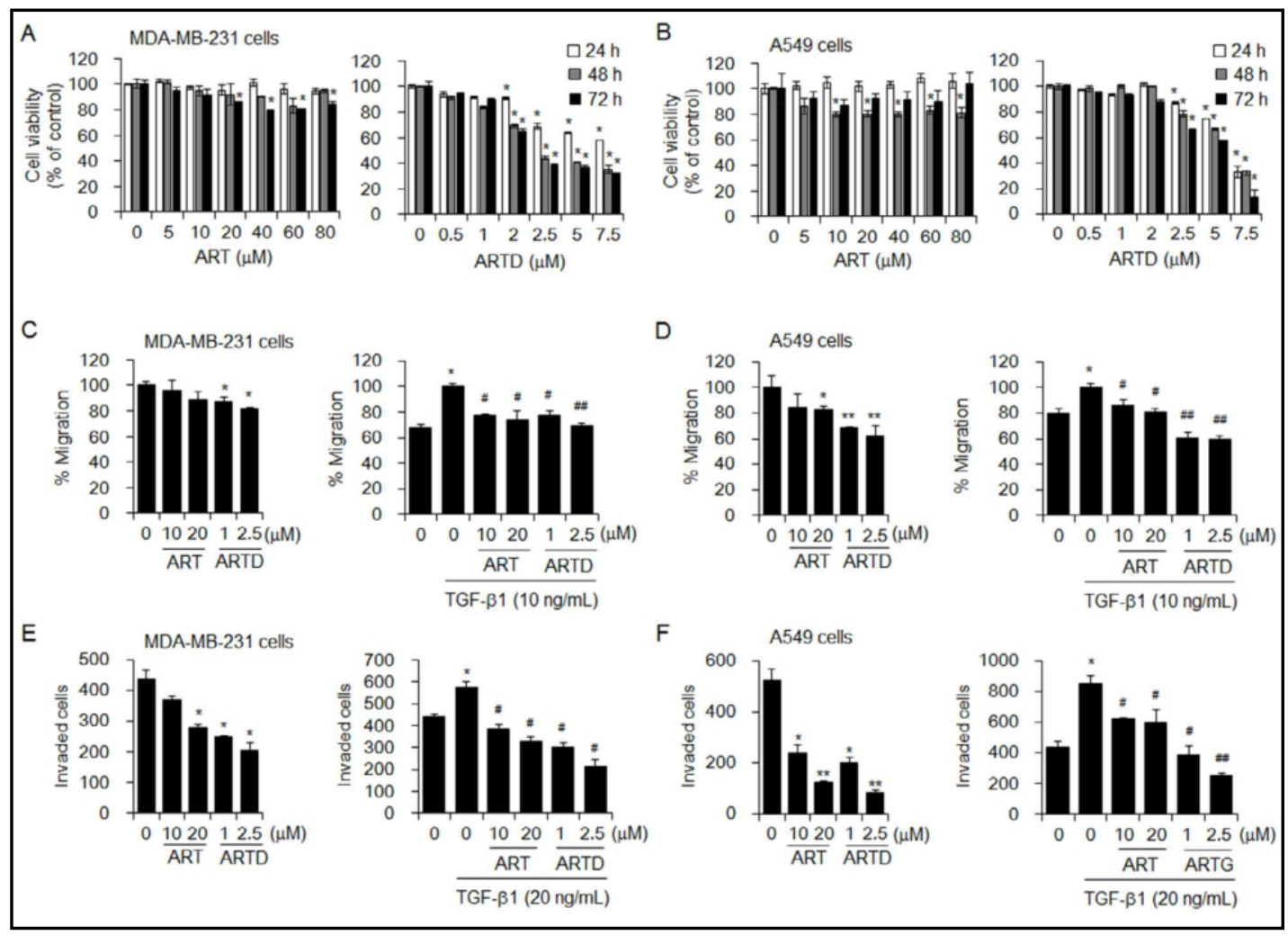

Fig. 3. The inhibitory effects of ARTD on the metastatic ability of MDA-MB-231 and A549 cells. (A, B) The viability of MDA-MB-231 and A549 cells treated with the indicated concentrations of artemisinin (ART) and ARTD for 24, 48, and $72 \mathrm{~h}$. Cell viability was determined by the MTT assay. (C, D) The migration and (E, F) invasion of MDA-MB-231 and A549 cells treated with the indicated concentrations of ART and ARTD in the absence or presence of TGF- $\beta$ for $24 \mathrm{~h}$. Cell migration is indicated as the percentage of wound closure at 24 $\mathrm{h}$ compared to that at $0 \mathrm{~h}$. The number of invaded cells was counted in five random fields per membrane. Data are expressed as the mean \pm SEM. ${ }^{*} \mathrm{P}<0.05$; ${ }^{* *} \mathrm{P}<0.01$ versus untreated cells, ${ }^{\#} \mathrm{P}<0.05$; ${ }^{\#} \mathrm{P}<0.01$ versus cells treated with TGF- $\beta$ only.

reduced by oral administration of ARTD at $5 \mathrm{mg} / \mathrm{kg}$ (Fig. 6B). Oral administration of ARTD blocked the OVX-induced decreases in BV/TV and Tb.N values and the OVX-induced increases in Tb.Sp and SMI values (Fig. 6C). H\&E staining also indicated that ARTD administration inhibited bone loss (Fig. 6D). TRAP staining and osteoclast surface per bone surface (Oc.S/ BS) values derived from stained femoral sections showed that the formation of TRAP-positive osteoclasts on trabecular bone surfaces was suppressed by ARTD treatment (Fig. 6D and E). ARTD treatment remarkably reduced the serum levels of osteocalcin in OVX mice compared to those of sham mice. However, ARTD treatment did not significantly inhibit OVX-induced serum levels of ALP, calcium, TRAP 5b, or CTX (Fig. 6F). In addition, ARTD treatment of OVX mice inhibited increases in the serum levels of TNF- $\alpha$ and IL-1 $\beta$ (Fig. 6G).

\section{Discussion}

Artemisinin with an endoperoxide moiety can produce cytotoxic free radicals by reacting with cellular iron. Artemisinin and its analogs selectively cause apoptosis in cancer cells, which have considerably more intracellular free iron than normal cells. These compounds are safer but less potent than traditional chemotherapeutic agents because of their low bioavailability and short plasma half-lives in humans. Therefore, more potent and target-selective artemisinin compounds for clinical application should be developed. In this study, we determined the therapeutic potential of ARTD for inhibiting cancer-mediated bone destruction and verified that binding of the natural glycolipid daumone to artemisinin could 


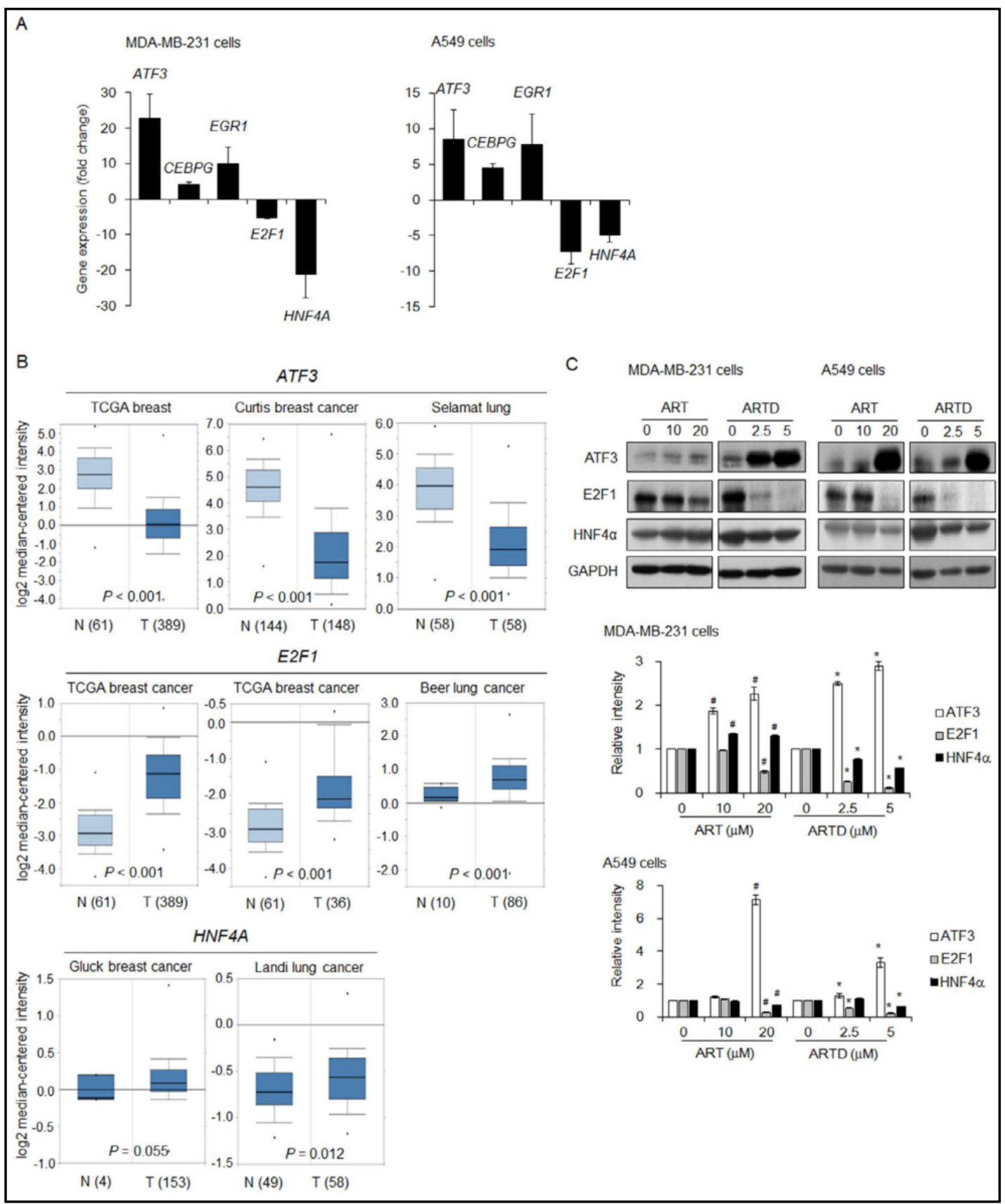

Fig. 4. Transcription factors regulated by ARTD in breast and lung cancer cells. (A) Altered mRNA expression levels of transcription factors in ARTD-treated cancer cells. RT ${ }^{2}$ profiler PCR arrays for human transcription factors were performed in MDA-MB-231 or A549 cells treated with ARTD (5 $\mu$ M) for $24 \mathrm{~h}$ as described in MATERIALS AND METHODS. Changes in gene expression are expressed as fold changes compared with the gene expression levels in untreated cells and as the mean \pm SEM. (B) Gene expression levels of transcription factors regulated by ARTD in normal and tumor tissues. Box plots were extracted from the Oncomine database. N: normal tissue; T: tumor tissue. (C) Protein expression of transcription factors targeted by ARTD. MDA-MB-231 or A549 cells were treated with artemisinin (ART) or ARTD at the indicated concentrations for $24 \mathrm{~h}$. The protein expression levels were examined by Western blot analysis. GAPDH served as the loading control. 


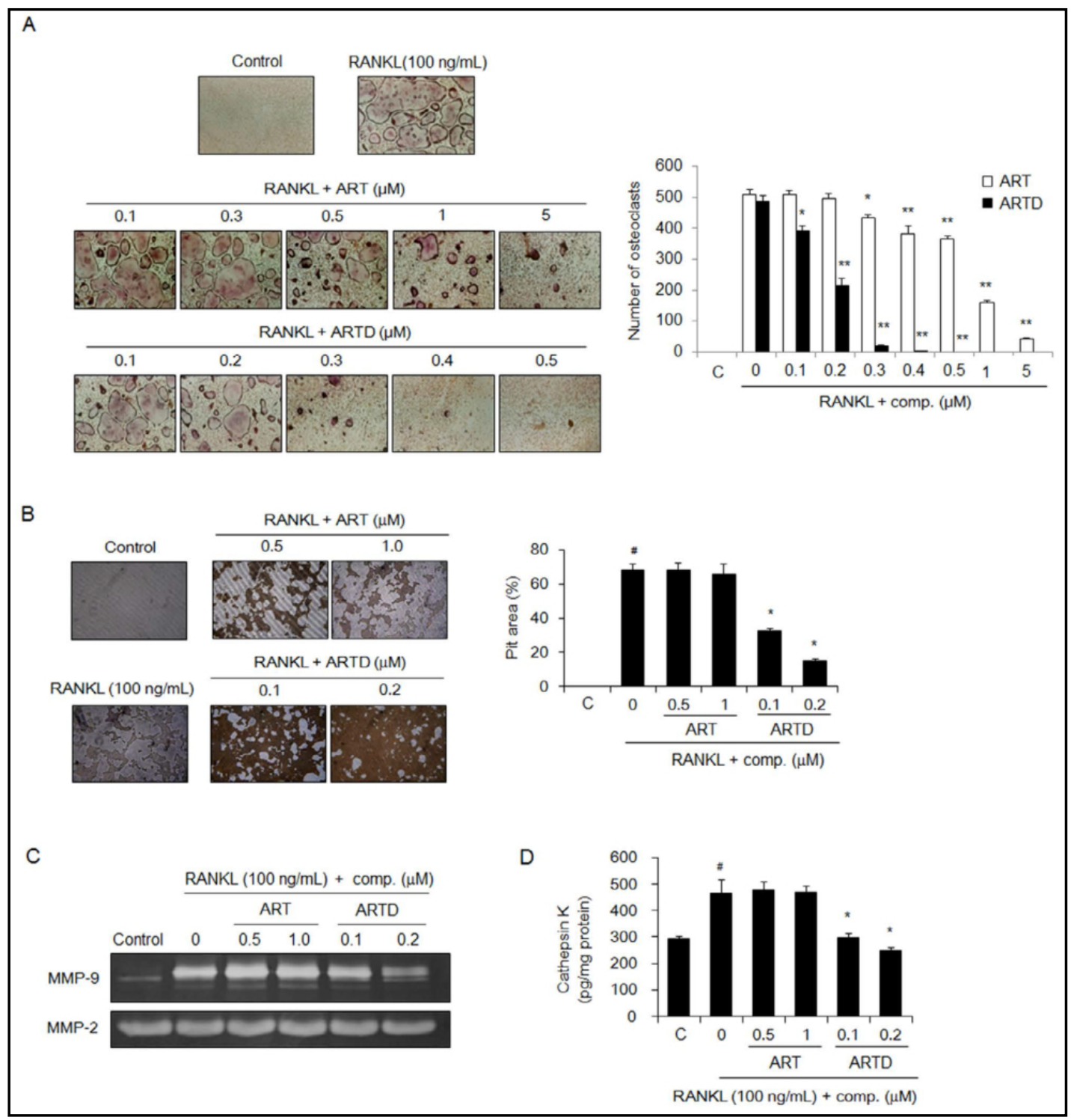

Fig. 5. Antiosteoclastogenic and anti-bone resorptive activities of ARTD. (A) Osteoclast formation. BMMs were incubated in $\alpha$-MEM with M-CSF, RANKL, and the indicated concentrations of artemisinin (ART) or ARTD for 5 days. TRAP-positive multinucleated cells ( $\geq 3$ nuclei) were counted as osteoclasts. (B-D) After BMMs had differentiated into mature osteoclasts on Osteo Assay Surface Plates, the cells were treated with the indicated concentrations of ART and ARTD for an additional 8 days. (B) Bone resorption. The resorption pits were observed using a light microscope (magnification, $\times 100$ ), and the resorbed area was calculated using ImageJ software. (C) MMP activity. The activities of MMP-2 and MMP-9 in the culture media were detected by gelatin zymography. (D) Cathepsin K activity. Cathepsin K activity in the culture media was detected using the SensiZyme cathepsin K activity assay kit. Data are expressed as the mean \pm SEM. ${ }^{\#} \mathrm{P}<0.05$ versus control (C), ${ }^{*} \mathrm{P}<0.05$ versus BMMs treated with RANKL only.

remarkably improve the anticancer and anti-bone resorptive activities of artemisinin.

Despite many differences between breast cancer and lung cancer, including their causes and mortality rates, bone metastases in breast cancer and NSCLC are classified as osteolytic. The production of severe osteolytic lesions by bone metastases is caused by increasing interactions among tumor cells, osteoblastic/stromal cells, and osteoclastic cells. The tumor cells release several cytokines, including interleukin (IL)-1 $\beta$, IL-6, and parathyroid hormonerelated protein. These released cytokines stimulate RANKL expression in osteoblastic/ 


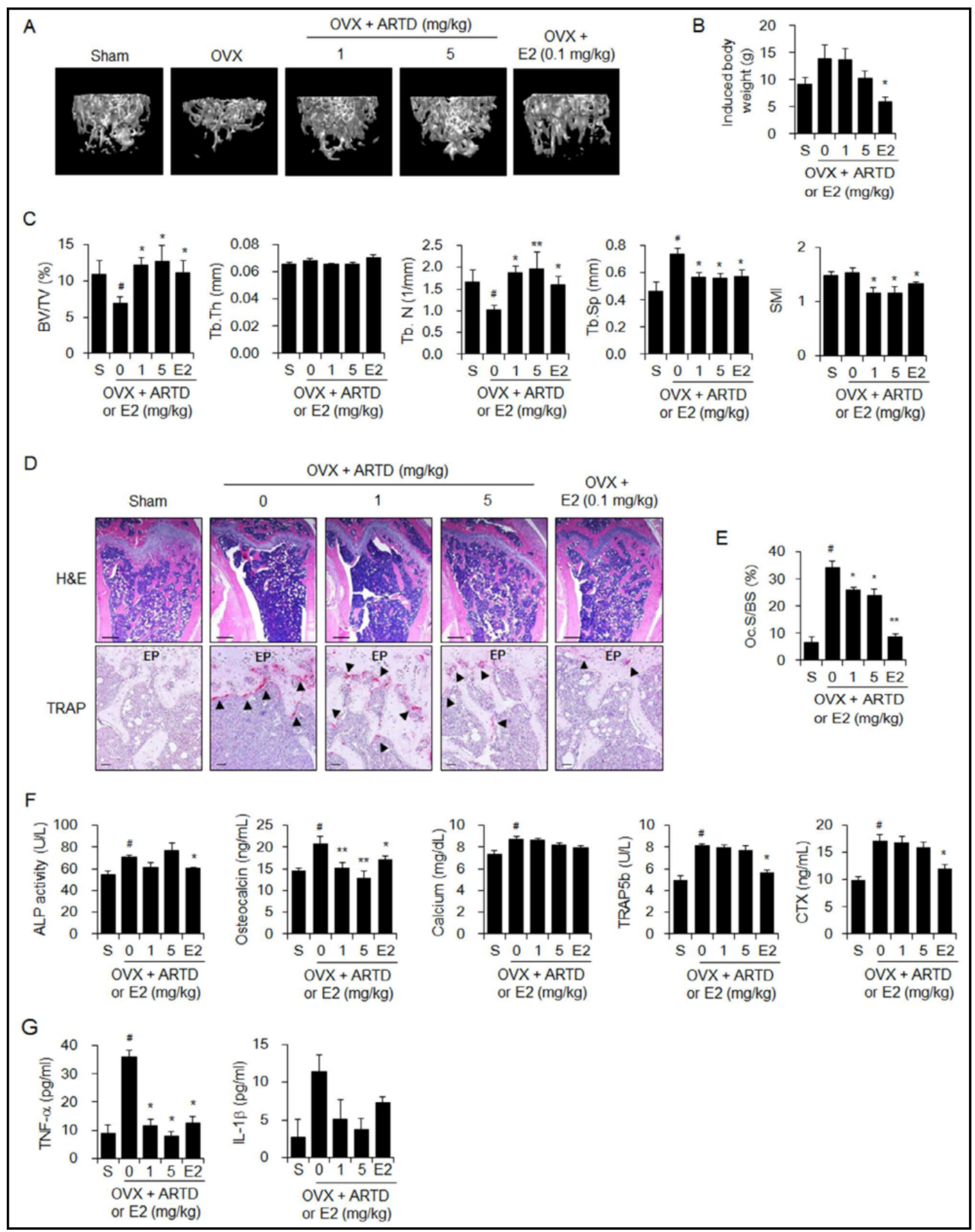

Fig. 6. The inhibitory effects of ARTD on estrogen deficiency-related bone loss in OVX mice. Eight-week-old female OVX mice ( $\mathrm{n}=10$ ) were administered vehicle, ARTD ( 1 or $5 \mathrm{mg} / \mathrm{kg})$, or E2 $(0.1 \mathrm{mg} / \mathrm{kg})$ by oral gavage 5 times per week for 12 weeks. Sham-operated mice $(n=10)$ received the vehicle only. (A) 3D images of the trabecular bones of mouse distal femora derived from $\mu$ CT scans. (B) Body weight measured on week 12. (C) Bone morphometric parameters of the mouse femora. (D) H\&E and TRAP staining of femoral tissues. Arrowheads: TRAP-positive osteoclasts; EP: epiphyseal plate. Scale bar: $0.246 \mathrm{~mm}$ for H\&E staining and 10 $\mu \mathrm{m}$ for TRAP staining. (E) Osteoclast surface per bone surface (Oc.S/BS) values for stained femoral sections. (F) Serum levels of bone turnover markers. (G) Serum levels of the pro-inflammatory cytokines TNF- $\alpha$ and IL-1 $\beta$. The data are expressed as the mean \pm SEM. ${ }^{*} \mathrm{P}<0.01$ versus sham-operated mice $(\mathrm{S}),{ }^{*} \mathrm{P}<0.05$; $* * \mathrm{P}<0.01$ versus OVX mice.

\section{KARGER}




\section{Cellular Physiology Cell Physiol Biochem 2018;49:1460-1475 \\ \begin{tabular}{l|l|l} 
and Biochemistry 10.1159/000493449 & $\begin{array}{l}\text { (c) } 2018 \text { The Author(s). Published by S. Karger AG, Basel } \\
\text { www.karger.com/cpb }\end{array}$
\end{tabular} \\ Ma et al.: Artemisinin-Daumone Hybrid Inhibits Cancer Cell-Mediated Osteolysis}

stromal cells, and soluble and membrane-bound RANKL induces osteoclast differentiation and subsequent bone resorption. TGF- $\beta 1$ derived from the resorbed bone promotes tumor growth and the release of cytokines from tumor cells. Repeated interactions between tumor cells and the bone microenvironment aggravate osteolysis [27, 28].

We first found that ARTD administration inhibited breast cancer cell-mediated bone loss in tibiae of mice inoculated with metastatic breast cancer or NSCLC cells. Orally administered ARTD at $20 \mathrm{mg} / \mathrm{kg}$ evidently prevented the growth of the cancer cells and the production of osteolytic lesions without having toxic effects on the liver and kidneys as shown by $\mu \mathrm{CT}$ images, bone morphometric parameters, histological examinations, and serum markers of bone turnover and tissue damage. However, oral administration of artemisinin at the same dose did not cause these inhibitory effects. The inhibitory effects of ARTD treatment were not as potent as those induced by subcutaneous injection of zoledronic acid. However, ATRD at $20 \mathrm{mg} / \mathrm{kg}$ was as effective as $10 \mathrm{mg} / \mathrm{kg}$ gefitinib, which is a selective epidermal growth factor receptor tyrosine kinase inhibitor clinically applied for cancer therapy [29].

The in vivo inhibitory activity of ARTD on cancer cell-mediated osteolysis was confirmed in cell-based experiments. ARTD treatment at noncytotoxic concentrations dose-dependently inhibited the viability, migration, and invasion of MDA-MB-231 breast cancer and A549 lung cancer cells treated with TGF- $\beta$ or not. In addition, we identified ATF3, E2F1, and HNF4 $\alpha$ as ARTD-regulated transcription factors. ATF3, a member of the ATF/cyclic AMP response element-binding family, is an adaptive-response gene that participates in cellular processes for adapting to extra- and intracellular stimuli. Upregulated ATF3 suppresses migration and invasion in several cancer cell types [30-32]; therefore, novel and specific ATF3 inducers are considered anticancer drug candidates. E2F1 transcriptionally regulates many biological functions that are deregulated in cancers $[33,34]$. Recent studies have reported that increased E2F1 expression causes invasion and metastasis by activating growth receptor signaling pathways and promoting an antiapoptotic tumor microenvironment $[35,36]$. $\mathrm{HNF} 4 \alpha$, a nuclear receptor expressed in liver and intestinal epithelial cells, appears to repress chronic and pathological inflammation [37] and epithelial-to-mesenchymal transition in hepatocytes [38]. In contrast, HNF $4 \alpha$ has been reported as a marker for invasive mucinous adenocarcinoma of the lung [39] and for distinction between primary and metastatic breast and gastric carcinoma [40].

In analyses using the Oncomine public database, the mRNA levels of ATF3 were reduced and those of E2F1 were increased significantly in breast or lung tumor tissues compared with those in normal tissues, demonstrating that ATF3 and E2F1 gene expression levels are closely correlated with tumors. In contrast, HNF4 $\alpha$ mRNA levels were increased in tumor tissues but had a statistically significant correlation with only lung cancer tissues. ARTD treatment upregulated the mRNA and protein levels of ATF3 and downregulated those of E2F1 and HNF4 $\alpha$ in both MDA-MB-231 and A549 cells. These results indicate that ARTD inhibits the malignant properties of breast and lung cancer cells by regulating the expression levels of transcription factors with prognostic significance, particularly tumor suppressive ATF3 and oncogenic E2F1. ARTD treatment resulted in significant inhibition at much lower concentrations than artemisinin treatment and more potent inhibition in A549 lung cancer cells than in MDA-MB-231 breast cancer cells.

Osteoclast activity is a critical factor in the vicious cycle of cancer-induced osteolytic bone destruction $[27,28]$. The differentiation of osteoclast precursors to mature osteoclast is triggered by the binding of RANKL to its receptor RANK on osteoclast precursors [41]. Mature osteoclasts cause severe bone resorption by secreting proteases and protons [42, 43]. Inhibitors of MMPs and cathepsin $\mathrm{K}$ have been considered as promising therapeutic candidates for osteoclast-related diseases [44, 45]. ARTD at noncytotoxic concentrations remarkably inhibited RANKL-induced osteoclast formation, mature osteoclast-mediated pit formation, and MMP-9 and cathepsin K secretion from mature osteoclasts. The antiosteoclastic and anti-bone resorptive effects of ARTD at lower concentrations were more potent than those of artemisinin. However, treatment with artemisinin and ARTD did not block an increase in RANKL level and a decrease in OPG level in osteoblastic cells stimulated with conditioned medium of cancer cells (Fig. S3). These results indicate that ARTD contributes to the mitigation of cancer-induced osteolysis by targeting osteoclasts.

We further investigated whether ARTD could inhibit estrogen deficiency-related bone loss. Oral administration of ARTD suppressed estrogen deficiency-induced bone loss by inhibiting the OVX-induced alterations in bone morphometric parameters and bone turnover 


\section{Cellular Physiology Cell Physiol Biochem 2018;49:1460-1475 \begin{tabular}{ll|l} 
and Biochemistry Published online: 13 September, 2018 & $\begin{array}{l}\text { (c) } 2018 \text { The Author(s). Published by S. Karger AG, Basel } \\
\text { www.karger.com/cpb }\end{array}$ \\
\hline
\end{tabular} \\ Ma et al.: Artemisinin-Daumone Hybrid Inhibits Cancer Cell-Mediated Osteolysis}

markers in mice. Moreover, ARTD treatment reduced pro-inflammatory cytokine TNF- $\alpha$ and IL- $\beta$ production in OVX mice. TNF- $\alpha$ and IL- $\beta$ are pro-inflammatory cytokines which is associated with osteoclastic bone resorption by stimulating RANKL expression $[46,47]$. Application of ARTD may be extended to patients with chemotherapy-induced premature ovarian failure or postmenopausal osteoporosis, similar to the existing therapeutic bisphosphonate agents.

\section{Conclusion}

ARTD inhibited breast and lung cancer-mediated bone loss by inhibiting the malignant properties of cancer cells via targeting of tumor suppressive ATF3 and oncogenic E2F1 and by blocking osteoclast formation and activity. In addition, ARTD prevented estrogen deficiency-induced bone loss. Hybridization of the glycolipid daumone to artemisinin noticeably promoted the anticancer and anti-bone resorption activity of artemisinin without detectable toxicity. Therefore, ARTD may be a useful agent for preventing and treating cancer-induced bone loss, and its application may be extended to chemotherapy-induced and postmenopausal bone loss.

\section{Acknowledgements}

We thank Chae-Eun Lee from the Oral Science Research Institute for providing technical assistance with $\mu \mathrm{CT}$. This work was carried out with the support of "Cooperative Research Program for Agriculture Science \& Technology Development (PJ011578)" Rural Development Administration, Republic of Korea.

\section{Disclosure Statement}

The authors declare no conflicts of interest.

\section{References}

1 Coleman RE: Metastatic bone disease: clinical features, pathophysiology and treatment strategies. Cancer Treat Rev 2001;27:165-176.

2 Yin JJ, Pollock CB, Kelly K: Mechanisms of cancer metastasis to the bone. Cell Res 2005;15:57-62.

3 Budczies J, von Winterfeld M, Klauschen F, Bockmayr M, Lennerz JK, Denkert C, Wolf T, Warth A, Dietel M, Anagnostopoulos I, Weichert W, Wittschieber D, Stenzinger A: The landscape of metastatic progression patterns across major human cancers. Oncotarget 2015;6:570-583.

4 Nielsen OS, Munro AJ, Tannock IF: Bone metastases: pathophysiology and management policy. J Clin Oncol 1991;9:509-524.

5 Coleman RE: Impact of bone-targeted treatments on skeletal morbidity and survival in breast cancer. Oncology (Williston Park) 2016;30:695-702.

6 Isla D, Afonso R, Bosch-Barrera J, Martinez N: Zoledronic acid in lung cancer with bone metastases: a review. Expert Rev Anticancer Ther 2013;13:421-426.

-7 Eastman RT, Fidock DA: Artemisinin-based combination therapies: a vital tool in efforts to eliminate malaria. Nat Rev Microbiol 2009;7:864-874.

8 Crespo-Ortiz MP, Wei MQ: Antitumor activity of artemisinin and its derivatives: from a well-known antimalarial agent to a potential anticancer drug. J Biomed Biotechnol 2012;2012:247597.

-9 Das AK: Anticancer Effect of antimalarial artemisinin compounds. Ann Med Health Sci Res 2015;5:93-102.

-10 Efferth T: Cancer combination therapies with artemisinin-type drugs. Biochem Pharmacol 2017;139:5670.

11 Ho WE, Peh HY, Chan TK, Wong WS: Artemisinins: pharmacological actions beyond anti-malarial. Pharmacol Ther 2014;142:126-139.

-12 Fortin S, Berube G: Advances in the development of hybrid anticancer drugs. Expert Opin Drug Discov 2013;8:1029-1047.

13 Meunier B: Hybrid molecules with a dual mode of action: dream or reality? Acc Chem Res 2008;41:69-77. 


\section{Cellular Physiology Cell Physiol Biochem 2018;49:1460-1475 \begin{tabular}{l|l|l} 
and Biochemistry $10.1159 / 000493449$ & $\begin{array}{l}\text { DO 2018 The Author(s). Published by S. Karger AG, Basel } \\
\text { www.karger.com/cpb }\end{array}$ \\
\hline
\end{tabular}

14 Muller-Schiffmann A, Sticht H, Korth C: Hybrid compounds: from simple combinations to nanomachines. BioDrugs 2012;26:21-31.

15 Sunil D, Kamath PR: Multi-target directed indole based hybrid molecules in cancer therapy : an up-to-date evidence-based review. Curr Top Med Chem 2017;17:959-985.

16 Teiten MH, Dicato M, Diederich M: Hybrid curcumin compounds: a new strategy for cancer treatment. Molecules 2014;19:20839-20863.

-17 Frohlich T, Ndreshkjana B, Muenzner JK, Reiter C, Hofmeister E, Mederer S, Fatfat M, El-Baba C, GaliMuhtasib H, Schneider-Stock R, Tsogoeva SB: Synthesis of novel hybrids of thymoquinone and artemisinin with high activity and selectivity against colon cancer. ChemMedChem 2017;12:226-234.

18 Lai HC, Singh NP, Sasaki T: Development of artemisinin compounds for cancer treatment. Invest New Drugs 2013;31:230-246.

19 Letis AS, Seo EJ, Nikolaropoulos SS, Efferth T, Giannis A, Fousteris MA: Synthesis and cytotoxic activity of new artemisinin hybrid molecules against human leukemia cells. Bioorg Med Chem 2017;25:3357-3367.

20 Tian Y, Liang Z, Xu H, Mou Y, Guo C: Design, synthesis and cytotoxicity of novel dihydroartemisinincoumarin hybrids via click chemistry. Molecules 2016;21.

21 Ricci J, Kim M, Chung WY, Park KK, Jung M: Discovery of artemisinin-glycolipid hybrids as anti-oral cancer agents. Chem Pharm Bull (Tokyo) 2011;59:1471-1475.

22 Jeong PY, Jung M, Yim YH, Kim H, Park M, Hong E, Lee W, Kim YH, Kim K, Paik YK: Chemical structure and biological activity of the Caenorhabditis elegans dauer-inducing pheromone. Nature 2005;433:541-545.

23 Mnif I, Ghribi D: Glycolipid biosurfactants: main properties and potential applications in agriculture and food industry. J Sci Food Agric 2016;96:4310-4320.

24 Kim HJ, Park J, Lee SK, Kim KR, Park KK, Chung WY: Loss of RUNX3 expression promotes cancerassociated bone destruction by regulating CCL5, CCL19 and CXCL11 in non-small cell lung cancer. J Pathol 2015;237:520-531.

-25 Lee SK, Park KK, Kim HJ, Park J, Son SH, Kim KR, Chung WY: Human antigen R-regulated CCL20 contributes to osteolytic breast cancer bone metastasis. Sci Rep 2017;7:9610.

-26 Kim KR, Kim HJ, Lee SK, Ma GT, Park KK, Chung WY: 15-deoxy-delta12, 14-prostaglandin j2 inhibits osteolytic breast cancer bone metastasis and estrogen deficiency-induced bone loss. PLoS One 2015;10:e0122764.

-27 Al Husaini H, Wheatley-Price P, Clemons M, Shepherd FA: Prevention and management of bone metastases in lung cancer: a review. J Thorac Oncol 2009;4:251-259.

28 Roodman GD: Mechanisms of bone metastasis. N Engl J Med 2004;350:1655-1664.

-29 D’Incecco A, Cappuzzo F: Gefitinib for non-small-cell lung cancer treatment. Expert Opin Drug Saf 2011;10:987-996.

30 Bar J, Hasim MS, Baghai T, Niknejad N, Perkins TJ, Stewart DJ, Sekhon HS, Villeneuve PJ, Dimitroulakos J: Induction of activating transcription factor 3 is associated with cisplatin responsiveness in non-small cell lung carcinoma cells. Neoplasia 2016;18:525-535.

-31 Gokulnath M, Partridge NC, Selvamurugan N: Runx2, a target gene for activating transcription factor-3 in human breast cancer cells. Tumour Biol 2015;36:1923-1931.

-32 Patacsil D, Tran AT, Cho YS, Suy S, Saenz F, Malyukova I, Ressom H, Collins SP, Clarke R, Kumar D: Gammatocotrienol induced apoptosis is associated with unfolded protein response in human breast cancer cells. J Nutr Biochem 2012;23:93-100.

-33 Engelmann D, Putzer BM: The dark side of E2F1: in transit beyond apoptosis. Cancer Res 2012;72:571-575.

-34 Meng P, Ghosh R: Transcription addiction: can we garner the Yin and Yang functions of E2F1 for cancer therapy? Cell Death Dis 2014;5:e1360.

-35 Abdraboh ME, Gaur RL, Hollenbach AD, Sandquist D, Raj MH, Ouhtit A: Survivin is a novel target of CD44promoted breast tumor invasion. Am J Pathol 2011;179:555-563.

-36 Pillai S, Trevino J, Rawal B, Singh S, Kovacs M, Li X, Schell M, Haura E, Bepler G, Chellappan S: betaarrestin-1 mediates nicotine-induced metastasis through E2F1 target genes that modulate epithelialmesenchymal transition. Cancer Res 2015;75:1009-1020.

37 Babeu JP, Boudreau F: Hepatocyte nuclear factor 4-alpha involvement in liver and intestinal inflammatory networks. World J Gastroenterol 2014;20:22-30.

-38 Santangelo L, Marchetti A, Cicchini C, Conigliaro A, Conti B, Mancone C, Bonzo JA, Gonzalez FJ, Alonzi T, Amicone L, Tripodi M: The stable repression of mesenchymal program is required for hepatocyte identity: a novel role for hepatocyte nuclear factor 4alpha. Hepatology 2011;53:2063-2074.

-39 Sugano M, Nagasaka T, Sasaki E, Murakami Y, Hosoda W, Hida T, Mitsudomi T, Yatabe Y: HNF4alpha as a marker for invasive mucinous adenocarcinoma of the lung. Am J Surg Pathol 2013;37:211-218. 


\section{Cellular Physiology Cell Physiol Biochem 2018;49:1460-1475 \begin{tabular}{ll|l} 
DOI: 10.1159/000493449 & $\begin{array}{l}\text { O 2018 The Author(s). Published by S. Karger AG, Basel } \\
\text { www.karger.com/cpb }\end{array}$ \\
\hline
\end{tabular} \\ Ma et al.: Artemisinin-Daumone Hybrid Inhibits Cancer Cell-Mediated Osteolysis}

40 Koyama T, Sekine S, Taniguchi H, Tsuda H, Ikegami M, Hano H, Kushima R: Hepatocyte nuclear factor 4A expression discriminates gastric involvement by metastatic breast carcinomas from primary gastric adenocarcinomas. Hum Pathol 2011;42:1777-1784.

41 Park JH, Lee NK, Lee SY: Current Understanding of RANK Signaling in Osteoclast Differentiation and Maturation. Mol Cells 2017;40:706-713.

-42 Andersen TL, del Carmen Ovejero M, Kirkegaard T, Lenhard T, Foged NT, Delaisse JM: A scrutiny of matrix metalloproteinases in osteoclasts: evidence for heterogeneity and for the presence of MMPs synthesized by other cells. Bone 2004;35:1107-1119.

43 Boyle WJ, Simonet WS, Lacey DL: Osteoclast differentiation and activation. Nature 2003;423:337-342.

44 Bi H, Chen X, Gao S, Yu X, Xiao J, Zhang B, Liu X, Dai M: Key Triggers of Osteoclast-Related Diseases and Available Strategies for Targeted Therapies: A Review. Front Med (Lausanne) 2017;4:234.

-45 Deng X, He G, Liu J, Luo F, Peng X, Tang S, Gao Z, Lin Q, Keller JM, Yang T, Keller ET: Recent advances in bonetargeted therapies of metastatic prostate cancer. Cancer Treat Rev 2014;40:730-738.

46 Hofbauer LC, Lacey DL, Dunstan CR, Spelsberg TC, Riggs BL, Khosla S: Interleukin-1beta and tumor necrosis factor-alpha, but not interleukin-6, stimulate osteoprotegerin ligand gene expression in human osteoblastic cells. Bone 1999;25:255-259.

47 Mundy GR: Osteoporosis and inflammation. Nutr Rev 2007;65:S147-151. 